\title{
TANGGUNG JAWAB NOTARIS ATAS KETERANGAN PALSU YANG DISAMPAIKAN PENGHADAP DALAM AKTA PENDIRIAN PERSEROAN TERBATAS
}

\author{
Nur Aini \\ Magister Kenotariatan, Fakultas Hukum, Universitas Surabaya \\ Email : ennyokey@gmail.com \\ Yoan Nursari Simanjuntak \\ Magister Kenotariatan, Fakultas Hukum, Universitas Surabaya
}

\begin{abstract}
ABSTRAK
Salah satu contoh permasalahan yang membawa Notaris ke dalam gugatan terjadi dalam perkara pendirian Perseroan Terbatas yang akta pendiriannya memuat keterangan palsu dari para penghadap. Penulis dalam penelitian ini ingin menelaah dan menganalisa lebih lanjut tentang akibat hukum terhadap akta pendirian Perseroan Terbatas yang dibuat berdasarkan keterangan palsu dan bentuk tanggung gugat Notaris atas akta pendirian Perseroan Terbatas yang dibuat berdasarkan keterangan palsu. Metode penelitian yang digunakan adalah penelitian hukum normatif. Hasil penelitian menunjukkan bahwa atas pendirian Perseroan Terbatas yang kesepakatan dari para pendirinya mengandung cacat kehendak karena adanya keterangan palsu dapat diajukan gugatan pembatalan pendirian kepada pengadilan untuk membatalkan perjanjian pendirian Perseroan Terbatas tersebut. Notaris dalam hal ini tidak bertanggungjawab maupun tidak dapat dimintakan tanggung gugat atas kerugian yang ditimbulkan dari adanya keterangan palsu penghadap.
\end{abstract}

Kata Kunci : Notaris, Keterangan Palsu, Tanggung Jawab

\section{ABSTRACT}

One example of a problem that brings a Notary to a claim occurs in the case of the establishment of a Limited Liability Company whose deed of establishment contains false information from the viewers. The author in this study wants to examine and analyze further about the legal consequences of the establishment of a Limited Liability Company based on false information and the form of notary accountability for the deed of establishment of a Limited Liability Company made based on false information. The research method used is normative legal research. The results of the study indicate that the establishment of a Limited Liability Company whose agreement from its founders contained a disability because a false statement could be filed against the establishment of the court to cancel the agreement to establish the Limited Liability Company. The notary in this case is neither responsible nor cannot be held accountable for the losses arising from the existence of false information on the face.

Keywords: Notary, False Information, Responsibility

\section{Pendahuluan}

Tujuan dibuatnya akta dihadapan Notaris adalah sebagai alat bukti yang kuat jika suatu saat terjadi perselisihan antara para pihak atau ada gugatan secara perdata maupun tuntutan secara pidana dari pihak lain. Jika terjadi 
suatu gugatan perdata maupun tuntutan pidana dari salah satu pihak maka tidak menutup kemungkinan notaris akan tersangkut dalam persoalan para pihak yang berperkara berkenaan dengan akta yang dibuat oleh Notaris.

Dalam praktik banyak ditemukan, jika ada akta notaris dipermasalahkan oleh para pihak atau pihak ketiga lainnya, maka sering pula notaris ditarik sebagai pihak yang turut serta melakukan atau membantu melakukan suatu tindak pidana, yaitu membuat atau memberikan keterangan palsu ke dalam akta notaris. Dalam hal ini notaris secara sengaja atau tidak disengaja notaris bersama-sama dengan pihak/penghadap untuk membuat akta dengan maksud dan tujuan untuk menguntungkan pihak atau penghadap tertentu saja atau merugikan penghadap yang lain harus dibuktikan di Pengadilan (Habib Adjie, 2008:78).

Pada kenyataannya yang terjadi di dalam masyarakat banyak ditemukan adanya para pihak yang memberikan data dan informasi tidak sesuai dengan kenyataannya kepada notaris dalam pembuatan suatu akta. Tugas seorang notaris adalah menuangkan data dan informasi yang diberikan oleh para pihak tanpa menginvestigasi lebih lanjut kebenaran data tersebut. Sebagaimana kita ketahui bersama, notaris tidak memiliki kewenangan melakukan investigasi atau mencari kebenaran materiil dari data dan informasi yang diberikan oleh para pihak (penghadap). Hal tersebut berdampak pada akta yang dibuatnya yang dikemudian hari menjadi bermasalah. Timbul persoalan dalam hal bentuk pertanggungjawaban notaris terhadap proses pembuatan akta otentik yang data dan informasinya dipalsukan oleh para pihak (Habib Adjie, 2008:29).

Salah satu contoh permasalahan yang membawa Notaris ke ranah gugatan terjadi dalam pendirian Perseroan Terbatas X (PT. X) yang berkedudukan di Jakarta Selatan. Dalam Perkara tersebut Tuan A mengajukan gugatan kepada Pengadilan Negeri Surabaya untuk membatalkan Akta Pendirian PT. $X$ yang dibuat dihadapan Notaris Z karena terdapat pemalsuan data dalam identitas pendiri PT. X. Pada gugatan yang diajukan oleh Tuan A selaku Penggugat, yang bersangkutan mendalilkan bahwa terdapat cacat kehendak dalam pendirian PT. $X$ karena salah satu pendiri PT. $X$ memberikan data identitas yang palsu pada saat membuat akta pendirian PT. X dihadapan Notaris Z. Keterangan Palsu tersebut diduga diberikan oleh Nyonya B yang pada saat pembuatan tidak memberitahukan bahwa yang bersangkutan memiliki kewarganegaraan Singapura.

Saat pembuatan akta PT. X pada tanggal 8 Agustus 2005, Nyonya B menggunakan identitas berupa Kartu Tanda Penduduk Republik Indonesia, sementara menurut Tuan A, yang bersangkutan telah memiliki kewarganegaraan Singapura sejak 23 Maret 2004 atau lebih dari 1 (satu) tahun sebelum pendirian PT. X. Atas kondisi tersebut, Tuan A mengajukan gugatan pembatalan 
akta pendirian PT. X karena terdapat cacat kehendak dalam perjanjian pendirian PT. $X$ tersebut. Cacat kehendak tersebut dinyatakan bahwa apabila Nyonya B tidak melakukan penipuan terkait maka yang bersangkutan tidak akan membuat perjanjian tersebut. Ketentuan Pasal 1328 KUHPerdata yang menyatakan : "Penipuan merupakan suatu alasan untuk membatalkan suatu persetujuan, bila penipuan yang dipakai oleh salah satu pihak adalah sedemikian rupa, sehingga nyata bahwa pihak yang lain tidak akan mengadakan perjanjian itu tanpa adanya tipu muslihat. Penipuan tidak dapat hanya dikira-kira, melainkan harus dibuktikan". Sehingga atas dasar itulah A mengajukan gugatan.

Dalam dasar gugatan yang diajukan oleh Tuan A disebutkan pula bahwa Notaris Z ditempatkan sebagai Tergugat karena sebagai Notaris dianggap bertindak kurang cermat atau secara tidak teliti dan hati-hati memasukkan identitas Nyonya B sebagai Warga Negara Indonesia. Oleh karena itu Notaris Z dianggap telah melakukan perbuatan melawan hukum. Adanya permasalahan yang diuraikan diatas melahirkan beberapa akibat hukum diantaranya bagaimana keabsahan akta pendirian Perseroan Terbatas yang didalamnya memuat keterangan palsu yaitu keterangan dari penghadap atas kewarganegaraan yang dimilikinya dan bagaimana tanggung gugat Notaris apabila akta yang telah dibuat mengandung keterangan palsu dari penghadap.

\section{Rumusan Masalah}

1. Apa akibat hukum terhadap akta pendirian Perseroan Terbatas yang dibuat berdasarkan keterangan palsu?

2. Apa bentuk tanggung gugat Notaris atas akta pendirian Perseroan Terbatas yang dibuat berdasarkan keterangan palsu?

\section{Metode Penelitian}

Penelitian ini menggunakan metode penelitian hukum normatif yang dilakukan untuk mencari pemecahan masalah atas permasalahan hukum yang ada. Pendekatan penelitian yang digunakan adalah pendekatan undang-undang (statute approach) dan pendekatan konseptual (conceptual approach).

\section{Pembahasan}

\section{Akibat Hukum Terhadap Akta Pendirian Perseroan Terbatas Yang Dibuat Berdasarkan Keterangan Palsu}

Akta otentik sebagai alat bukti terkuat dan terpenuh mempunyai peranan penting dalam setiap hubungan hukum dalam kehidupan masyarakat. Dalam berbagai hubungan bisnis, kegiatan di bidang perbankan, pertanahan, kegiatan sosial, dan lain-lain, kebutuhan akan pembuktian tertulis berupa akta otentik makin meningkat sejalan dengan berkembangnya tuntutan akan kepastian hukum dalam berbagai hubungan ekonomi dan sosial, baik pada tingkat nasional, regional, maupun global. Dengan adanya akta otentik yang menentukan secara jelas hak dan kewajiban masing-masing pihak diharapkan mampu menjamin kepastian hukum 
dan sekaligus diharapkan pula dapat menghindari terjadinya sengketa. Ataupun apabila sengketa tersebut tidak dapat lagi dihindari, diharapkan akta otentik yang merupakan alat bukti tertulis terkuat dan terpenuh memberi sumbangan nyata bagi penyelesaian perkara secara murah dan cepat.

Demi menjamin kepastian hukum tersebut, dibutuhkan alat bukti tertulis yang bersifat otentik mengenai keadaan, peristiwa atau perbuatan hukum yang dapat diperoleh melalui pembuatan akta dihadapan Pejabat Umum yaitu Notaris.(Hatta Isnaini Wahyu Utomo, 2019: 41) Hal ini sesuai dengan rumusan Pasal 1868 yang menyatakan bahwa: "Suatu akta otentik ialah suatu akta yang dibuat dalam bentuk yang ditentukan undang-undang oleh atau dihadapan pejabat umum yang berwenang untuk itu di tempat akta itu dibuat".

Menurut Habib Adjie, Pasal 1868 BW memberikan batasan secara unsur yang dimaksud dengan akta otentik:

1. Akta itu harus dibuat oleh (door) atau di hadapan (ten overstaan) seorang Pejabat Umum.

2. Akta itu harus dibuat dalam bentuk yang ditentukan oleh undang-undang.

3. Pegawai Umum (Pejabat Umum) oleh atau di hadapan siapa akta itu dibuat, harus mempunyai wewenang untuk membuat akta tersebut. (Habib Adjie, 2011:33),

Notaris, yang dalam Bahasa Inggris disebut dengan notary, sedangkan dalam bahasa Belanda disebut dengan van notaris, mempunyai peranan yang sangat penting dalam lalu lintas hukum, khususnya dalam bidang hukum keperdataan, karena Notaris berkedudukan sebagai pejabat umum, yang mempunyai kewenangan untuk membuat akta otentik dan kewenangan lainnya (Salim HS, 2015:121). Wawan Setiawan menegaskan bahwa Pejabat Umum adalah organ negara yang di perlengkapi dengan kekuasaan umum, berwenang menjalankan sebagian dari kekuasaan umum, berwenang menjalankan sebagian dari kekuasaan Negara untuk membuat alat bukti tertulis dan otentik dalam hukum perdata. (Setiawan, 2001:8)

Pengertian Notaris secara otentik terdapat dalam ketentuan Pasal 1 Undang-Undang Nomor 30 tahun 2004 tentang Jabatan Notaris sebagaimana telah diubah dengan Undang-Undang Nomor 2 tahun 2014 tentang Perubahan Atas Undang-Undang Nomor 30 tahun 2004 tentang Jabatan Notaris (UUJN), menyebutkan bahwa Notaris adalah pejabat umum yang berwenang untuk membuuat akta otentik dan kewenangan lainnya sebagaimana dimaksud dalam Undang-Undang ini.

Notaris dalam melaksanakan tugas dan kewajibannya harus sesuai dengan Peraturan Perundang-Undangan yang berlaku, kewajiban merupakan sesuatu yang harus dilaksanakan agar akta yang dibuat menjadi akta autentik. Notaris sebagai pejabat umum bertugas untuk memberikan pelayanan kepada anggota masyarakat yang memerlukan jasanya dalam pembuatan alat bukti tertulis, khususnya berupa akta 
autentik dalam bidang hukum perdata. Keberadaan Notaris merupakan pelaksanaan dari hukum pembuktian (Herlien Budiono, 2013:31).

Akta yang dibuat oleh Notaris dapat menjadi alas hukum atas status harta benda, hak, dan kewajiban seseorang. Kesalahan atas akta yang dibuat Notaris dapat menyebabkan tercabutnya hak seseorang atau terbebaninya seseorang atas suatu kewajiban. Akta otentik pada hakikatnya memuat kebenaran formal sesuai dengan apa yang diberitahukan para pihak kepada Notaris. Namun, Notaris mempunyai kewajiban untuk memasukkan bahwa apa yang termuat dalam Akta Notaris sungguh-sungguh telah dimengerti dan sesuai dengan kehendak para pihak, yaitu dengan cara membacakannya sehingga menjadi jelas isi Akta Notaris, serta memberikan akses terhadap informasi, termasuk akses terhadap peraturan perundang-undangan yang terkait bagi para pihak penanda tangan akta. Dengan demikian, para pihak dapat menentukan dengan bebas untuk menyetujui atau tidak menyetujui isi Akta Notaris yang akan ditandatanganinya.(Hatta Isnaini Wahyu Utomo, 2017:24)

Akta otentik secara teoritis adalah surat atau akta yang sejak semula dengan sengaja secara resmi dibuat untuk pembuktian, dimana pembuktian itu dilakukan jikalau terjadi sengketa dikemudian hari. Apabila suatu akta merupakan akta otentik, maka akta tersebut akan mempunyai 3 (tiga) fungsi terhadap para pihak yang membuatnya yaitu (Salim H.S, 2006:43) :

1. Sebagai bukti bahwa para pihak yang bersangkutan telah mengadakan perjanjian tertentu;

2. Sebagai bukti bagi para pihak bahwa apa yang tertulis dalam perjanjian adalah menjadi tujuan dan keinginan para pihak;

3. Sebagai bukti kepada pihak ketiga bahwa pada tanggal tertentu kecuali jika ditentukan sebaliknya para pihak telah mengadakan perjanjian dan bahwa isi perjanjian adalah sesuai dengan kehendak para pihak.

Menurut K. Wantjik Saleh, berdasarkan Undang-Undang suatu akta resmi mempunyai kekuatan pembuktian yang sempurna (Volledig Bewijs), artinya apabila suatu pihak memajukan suatu akta resmi, hakim harus menerimanya dan menganggap bahwa apa yang dituliskan dalam akta itu sungguhsungguh telah terjadi, sehingga hakim tidak boleh memerintahkan penambahan pembuktian lagi (K. Wantjik Saleh, 1981:62).

Salah satu bentuk perjanjian yang dibuat dengan akta otentik adalah pendirian Perseroan Terbatas (PT). Pada pendirian PT, perbuatan hukum pendirian oleh 2 (dua) atau lebih pendiri tidak melahirkan perjanjian antara para pendiri, melainkan mengakibatkan adanya perjanjian antara semua pendiri disatu pihak dan PT di pihak lain. Berdasarkan perjanjian pendirian dimaksud para pendiri berhak menerima saham dalam PT dan sekaligus mereka wajib melakukan penyetoran penuh atas saham yang diambilnya (Fred B.G. 
Tumbuan, 2007:42). Dengan demikian maka pendirian PT sebagai persekutuan modal diantara pendiri dan/atau pemegang saham, harus memenuhi ketentuan hukum perjanjian yang diatur dalam Buku Ketiga KUHPerdata khususnya Bab Kedua, Bagian Kesatu tentang Ketentuan umum perjanjian (Pasal 1313-1319) dan Bagian Kedua tentang syarat-syarat sahnya perjanjian (Pasal 1320-1337), serta Bagian Ketiga tentang akibat perjanjian (Pasal 1338-1341).

Ditinjau dari segi hukum perjanjian, pendirian PT sebagai badan hukum, bersifat "kontraktual" (contractual, by contract) yakni berdirinya Perseroan merupakan akibat yang lahir dari perjanjian. Selain bersifat kontraktual, juga bersifat "konsensual" (consensuel, consensual) berupa adanya kesepakatan untuk mengikat perjanjian mendirikan Perseroan. Sesuai dengan ketentuan Pasal 7 ayat (1) UUPT, supaya perjanjian untuk mendirikan PT sah menurut undang-undang, pendirinya paling sedikit 2 (dua) orang atau lebih.(Hatta Isnaini Wahyu Utomo, 2017:28). Hal itu ditegaskan pada penjelasan Pasal 7 ayat (1) UUPT yang menyatakan bahwa prinsip yang berlaku berdasar undang-undang ini, Perseroan sebagai badan hukum didirikan berdasar perjanjian, oleh karena itu mempunyai lebih dari 1 (satu) orang pemegang saham. Dengan adanya perjanjian yang menjadi dasar pendirian PT, maka tentunya tunduk pula kepada syarat sahnya perjanjian yang disebutkan dalam Pasal 1320 KUHPerdata yaitu: 1) Adanya kesepakatan; 2)
Kecakapan; 3) Atas suatu hal tertentu; 4) Sebab (causa) yang halal. Pada syarat sahnya perjanjian, terdapat syarat subjektif yaitu syarat yang berkaitan dengan subjek yang mengadakan atau membuat perjanjian, yang terdiri dari kata sepakat dan cakap bertindak untuk melakukan suatu perbuatan hukum, dan syarat objektif yaitu syarat yang berkaitan dengan perjanjian itu sendiri atau berkaitan dengan objek yang dijadikan perbuatan hukum oleh para pihak, yang terdiri dari suatu hal tertentu dan sebab yang tidak dilarang.

Dalam hukum perjanjian ada akibat hukum tertentu jika syarat subjektif dan syarat objektif tidak terpenuhi. Jika syarat subjektif tidak terpenuhi, maka perjanjian dapat dibatalkan (vernietigbaar) sepanjang ada permintaan oleh orang-orang tertentu atau yang berkepentingan (Wirjono Prodjodikoro, 1989:61). Syarat subjektif ini senantiasa dibayangi ancaman untuk dibatalkan oleh para pihak yang berkepentingan dari orang tua, wali atau pengampu. Agar ancaman seperti itu tidak terjadi, maka dapat dimintakan penegasan dari mereka yang berkepentingan, bahwa perjanjian tersebut akan tetap berlaku dan mengikat para pihak. Jika syarat objektif tidak terpenuhi, maka perjanjian batal demi hukum (nietig), tanpa perlu ada permintaan dari para pihak, dengan demikian perjanjian dianggap tidak pernah ada dan tidak mengikat siapapun. Perjanjian yang batal mutlak dapat juga terjadi, jika suatu perjanjian yang dibuat tidak dipenuhi, padahal aturan hukum sudah menentukan 
untuk perbuatan hukum tersebut harus dibuat dengan cara yang sudah ditentukan atau berlawanan dengan kesusilaan atau ketertiban umum (Peter Mahmud Marzuki, 2003:132), karena perjanjian sudah dianggap tidak ada, maka sudah tidak ada dasar lagi bagi para pihak untuk saling menuntut atau menggugat dengan cara dan bentuk apapun (Subekti, 2005:29).

Akta notariil yang merupakan perjanjian para pihak mengikat bagi mereka yang membuatnya. Oleh karena itu, syarat-syarat sahnya suatu perjanjian harus dipenuhi. Syaratsyarat tersebut meliputi syarat subjektif yang berkaitan dengan subjek yang mengadakan atau membuat perjanjian, dan syarat objektif yang berkaitan dengan objek perjanjian. Syarat sahnya perjanjian harus diwujudkan dalam akta notariil. Syarat subjektif dicantumkan dalam awal akta, dan syarat objektif dicantumkan dalam badan akta sebagai isi akta.(Habib Adjie, 2008:75)

Unsur subjektif yang pertama berupa adanya kesepakatan antara para pihak. Yang dimaksud dengan kesepakatan adalah bahwa pihakpihak yang membuat perjanjian harus memberikan persetujuannya secara bebas, apa yang dikehendaki oleh pihak yang satu haruslah merupakan kehendak dari pihak lain. Dengan demikian kesepakatan tercapai apabila kedua pihak mempunyai kehendak yang sama secara timbal balik. Unsur subjektif yang kedua berupa adanya kecakapan bertindak. Kecakapan pada umumnya adalah mereka yang telah dewasa yang dikaitkan dengan umur dan tidak ditaruh di bawah pengampuan.

Keterangan palsu yang disampaikan penghadap dalam akta pendirian PT mengakibatkan suatu perjanjian tidak memenuhi syarat subyektif perjanjian karena terdapatnya cacat kehendak. Adapun yang dimaksud dengan perjanjian yang mengandung cacat dalam kehendak adalah perjanjianperjanjian yang "pada waktu lahirnya" mengandung cacat dalam kehendak. Pasal 1322 sampai dengan Pasal 1328 KUHPerdata mengatur tentang perjanjian yang telah ditutup atas dasar adanya cacat dalam kehendak. Ke dalam kelompok perjanjian yang mengandung cacat dalam kehendak dalam doktrin dimasukkan perjanjian-perjanjian yang mengandung unsur kesesatan, paksaan atau penipuan pada saat lahirnya perjanjian. Pada perjanjian yang mengandung cacat dalam kehendak, kehendak yang diberikan dalam perjanjian itu bukan didasarkan atas kehendak (sepakat) yang murni, sepakat di sana diberikan karena ia keliru, tertekan, tertipu atau di bawah pengaruh orang lain yang menyalahgunakan keadaan yang ada. Sehingga kondisi demikian bukan merupakan sepakat yang mestinya di berikan kalau ia tidak khilaf (keliru), tidak takut kepada tekanan yang ada, kalau kehendaknya tidak dibawa kepada gambaran yang tidak benar oleh lawan janjinya atau kepercayaannya tidak disalahmanfaatkan oleh lawan janjinya. (J.Satrio, 2018).

Pada pendirian PT yang kesepakatan dari para pendirinya mengandung cacat kehendak 
karena adanya keterangan palsu yang disampaikan oleh salah satu pendiri dan perjanjian tersebut telah dituangkan ke dalam akta Notaris, maka pihak yang dapat merasa dirugikan dapat mengajukan gugatan kepada pengadilan untuk membatalkan perjanjian pendirian PT tersebut. Adapun gugatan yang diajukan oleh pihak yang dirugikan dapat berupa gugatan untuk membatalkan isi perjanjian yang telah dituangkan ke dalam akta Notaris.

Akta Notaris yang dapat dibatalkan adalah akta pihak yang tidak memenuhi kedua unsur tersebut di atas. Pembatalan akta notariil adalah pernyataan batalnya suatu tindakan hukum atas tuntutan dari pihak yang oleh undangundang dibenarkan untuk menuntut pembatalan seperti itu. Di sini sebenarnya ada suatu tindakan hukum yang mengandung cacat, tetapi tindakan tersebut menurut undang-undang masih menimbulkan akibat hukum seperti yang diharapkan/dituju oleh si pelaku, hanya saja perjanjian yang timbul berdasarkan perjanjian itu, atas tuntutan dari pihak yang lain, dapat dibatalkan. Pembatalan dilakukan oleh hakim atas tuntutan pihak yang diberikan hak oleh undang-undang untuk menuntut seperti itu.

\section{Tanggung Gugat Notaris Atas Akta Yang Dibuat Berdasarkan Keterangan Palsu UUJN memberikan} kewenangan kepada notaris untuk memberikan penyuluhan hukum sehubungan dengan pembuatan akta dengan tujuan agar para pihak dapat memahami hukum yang berlaku, sehingga hukum tersebut dapat melembaga dan bahkan menjiwai setiap para pihak yang bersangkutan. Tujuannya bukan sekedar memberikan informasi atau keterangan-keterangan mengenai hukum yang perlu diketahui, akan tetapi mengusahakan untuk membina dan meningkatkan kesadaran hukum para pihak yang bersangkutan, sehingga timbul kepatuhan dan ketaatan hukum, atas dasar anggapan bahwa hukum itu sesuai dengan nilai-nilai yang berlaku atau yang dianutnya.(Hatta Isnaini Wahyu Utomo, 2017:29)

Atas dasar kewenangan tersebut, dalam menjalankan tugas dan kewajibannya notaris dituntut untuk memberikan jaminan kepastian hukum dan pelayanan yang profesional. Dalam mewujudkan 2 (dua) sisi pekerjaan yang mengandung banyak resiko tersebut diperlukan pengetahuan hukum yang cukup dan ketelitian serta tanggung jawab yang tinggi. Untuk itu dalam praktek sehari-hari notaris diwajibkan untuk senantiasa menjunjung tinggi hukum dan asas negara serta bertindak sesuai dengan makna sumpah jabatan dan mengutamakan pengabdiannya kepada kepentingan masyarakat dan negara. Adanya kewajiban kepribadian yang baik dan tuntutan untuk menjunjung tinggi martabat jabatan notaris, dengan demikian dalam pelaksanaan jabatannya notaris tidak dibenarkan melakukan hal-hal dan/atau tindakan yang tidak sesuai dengan martabat dan kehormatan jabatan notaris.

Jabatan Notaris mempunyai dua ciri dan sifat yang essential, 
ketidakmemihakkan dan kemandiriannya dalam memberikan bantuan kepada para kliennya. Adalah suatu credo, suatu keyakinan, bahwa kedua ciri tersebut melekat pada dan identik dengan perilaku pelaku jabatan ini (Herlien Budiono, 2015:281). Menurut Habib Adjie, meskipun secara administratif Notaris diangkat dan diberhentikan oleh pemerintah, tidak berarti Notaris menjadi subordinasi (bawahan) yang mengangkatnya pemerintah. Dengan demikian Notaris dalam menjalankan tugas jabatannya: a) Bersifat mandiri (autonomous); b) Tidak memihak siapapun (impartial); c) Tidak tergantung kepada siapapun (independent), yang berarti dalam menjalankan tugas jabatannya tidak dapat dicampuri oleh pihak yang mengangkatnya atau oleh pihak lain (Habib Adjie, 2008:16).

Kedudukan Notaris sebagai suatu jabatan yang terhormat dan memiliki peran sangat penting dalam masyarakat tentunya mengharuskan siapa yang memangku jabatan tersebut memiliki kualitas yang mumpuni baik secara keilmuan maupun kepemimpinan. Ilmu pengetahuan khususnya di bidang hukum harus benar-benar dipahami oleh Notaris secara mendalam. Hal tersebut tercermin dari salah satu syarat pengangkatan Notaris yang disebutkan dalam Pasal 3 huruf e UUJN adalah "Berijazah Sarjana Hukum dan lulus jenjang strata dua Kenotariatan".(Huddhan Ary, 2018:107)

$\begin{array}{cr}\text { Dalam } & \text { menjalankan } \\ \text { jabatannya secara } & \text { profesional }\end{array}$

dirasakan semakin penting karena kedudukan notaris sebagai pejabat umum berhadapan langsung dengan kepentingan masyarakat dalam memberikan bantuan pelayanan atau jasa. Apabila hal tersebut tidak diberikan secara baik atau profesional, maka nantinya terdapat pihak yang dirugikan sebagai akibat hukum dari kesalahan atau kelalaian yang telah diperbuat oleh notaris.(Ferdiansyah Putra, 2018:30)

Notaris sebagai lembaga negara yang independen adalah subyek hukum, sebagai pendukung hak dan kewajiban hukum, yang memiliki kedudukan hukum yaitu sebagai kepanjangan tangan dari pemerintah yang melayani kebutuhan masyarakat dalam pembuatan akta otentik. Sebagai subyek hukum Notaris dapat melakukan perbuatan hukum, yaitu perbuatan yang ada relevansinya dengan hukum atau perbuatan yang dapat menimbulkan akibat hukum. Dengan demikian, setiap bentuk dari perbuatan hukum, secara pasti akan menimbulkan akibat hukum baik yang positif maupun yang negatif. Akibat hukum yang negatif memiliki relevansi dengan tanggung-gugat karena dapat memunculkan tuntutan dari pihak yang terkena akibat hukum yang negatif yang biasa menimbulkan kerugian dari pihak tersebut.

Tanggung jawab notaris di dalam UUJN dimaksudkan sebagai keterikatan notaris terhadap ketentuan-ketentuan hukum dalam menjalankan tugas dan kewajibannya, dalam pengertian bahwa semua perbuatan notaris dalam menjalankan tugas 
kewajibannya harus dapat dipertanggungjawabkan secara hukum, termasuk dengan segala konsekuensinya untuk dikenakan sanksi hukum terhadap pelanggaran norma-norma hukum yang mendasarinya.

Pada saat akta yang dibuat oleh Notaris tersebut dikemudian hari bermasalah atau menimbulkan kerugian bagi salah satu pihak dalam akta, maka dalam hal ini notaris tidak bisa langsung dipersalahkan atau diminta pertanggung jawabannya, karena akta notaris tersebut adalah merupakan keinginan dan permintaan para pihak, bukan saran atau pendapat notaris, melainkan isi akta merupakan perbuatan para pihak dan bukan perbuatan atau tindakan notaris. Notaris hanya memformulasikan keinginan para pihak agar tindakannya dituangkan dalam bentuk akta otentik atau akta notaris. Pihak yang merasa dirugikan dan yang hendak menuntut notaris tersebut terlebih dahulu harus dapat membuktikan beberapa hal berikut ini : a) Adanya derita kerugian; b) Antara kerugian yang diderita dan pelanggaran atau kelalaian dari notaris terdapat hubungan kausal; c) Pelanggaran (perbuatan) atau kelalaian tersebut disebabkan kesalahan yang dapat dipertanggungjawabkan kepada notaris yang bersangkutan.

\section{Kondisi} sebagaimana diuraikan diatas berlaku pula terhadap Akta pendirian PT yang mengandung cacat kehendak karena adanya keterangan palsu dari penghadap. Secara prinsip, notaris bersifat pasif melayani para pihak yang menghadap kepadanya.
Notaris hanya bertugas mencatat atau menuliskan dalam akta apaapa yang diterangkan para pihak, tidak berhak mengubah, mengurangi atau menambah apa yang diterangkan para penghadap. Bagian penjelasan UUJN yang menyatakan bahwa Akta otentik pada hakikatnya memuat kebenaran formal sesuai dengan apa yang diberitahukan para pihak kepada Notaris. Hal tersebut ditegaskan pula melalui Yurisprudensi Mahkamah Agung dalam Putusan Mahkamah Agung Nomor 702 K/Sip/1973 Tanggal 5 September 1973 yang menyatakan “...Notaris fungsinya hanya mencatatkan /menuliskan apa-apa yang dikehendaki dan dikemukakan oleh para pihak yang menghadap Notaris tersebut. Tidak ada kewajiban bagi Notaris untuk menyelidiki secara materiil apa-apa (hal-hal) yang dikemukakan oleh penghadap di hadapan Notaris tersebut". Sehingga dengan demikian atas keterangan palsu yang disampaikan oleh para penghadap sepenuhnya menjadi tanggungjawab dari penghadap dan Notaris dalam hal ini tidak bertanggungjawab maupun tidak dapat dimintakan tanggung gugat atas kerugian yang ditimbulkan dari adanya keterangan palsu penghadap.

\section{Simpulan}

Akta otentik yang dibuat dihadapan Notaris adalah berdasarkan kehendak dari para pihak. Pada pendirian PT yang kesepakatan dari para pendirinya mengandung cacat kehendak karena adanya keterangan palsu 
yang disampaikan oleh salah satu pendiri dan perjanjian tersebut telah dituangkan ke dalam akta Notaris, maka pihak yang dapat merasa dirugikan dapat mengajukan gugatan kepada pengadilan untuk membatalkan perjanjian pendirian PT tersebut. Adapun gugatan yang diajukan oleh pihak yang dirugikan dapat berupa gugatan untuk membatalkan isi perjanjian yang telah dituangkan ke dalam akta Notaris.

\section{Notaris}

hanya

mengkonstantir dan memformulasikan dalam akta apaapa yang diterangkan para pihak berdasarkan perjanjian yang dilakukan oleh para pihak itu sendiri. atas keterangan palsu yang disampaikan oleh para penghadap sepenuhnya menjadi tanggungjawab dari penghadap dan Notaris dalam hal ini tidak bertanggungjawab maupun tidak dapat dimintakan tanggung gugat atas kerugian yang ditimbulkan dari adanya keterangan palsu penghadap.

\section{Saran}

Notaris diharapkan dapat menjalankan tugas jabatan secara profesional dan memiliki pengetahuan serta keilmuan yang mumpuni di bidang hukum, khususnya pemahaman mengenai Peraturan Perundang-Undangan yang berlaku di Indonesia serta selalu menerapkan prinsip kehatihatian dalam pelaksanaan tugas jabatannya.
Daftar Pustaka

Buku-Buku

Adjie, Habib, Hukum Notariat di Indonesia : Tafsir Tematik Terhadap UU No.30 Tahun 2004 Tentang Jabatan Notaris, Refika Aditama,Bandung, 2008

---, Kebatalan dan Pembatalan Akta Notaris, Refika Aditama, Bandung, 2011

Budiono, Herlien, Kumpulan Tulisan Hukum Perdata di Bidang Kenotariatan Buku Kedua, Citra Aditya Bakti, Bandung, 2013

HS, Salim, Teknik Pembuatan Akta Satu, Raja Grafindo Persada, Jakarta, 2015

Marzuki, Peter Mahmud, Penelitian Hukum, Kencana Prenada Media Group, Jakarta, 2011

Prodjodikoro, Wirjono, Azaz-Azaz Hukum Perjanjian, Bale Bandung "Sumur Bandung", 1989

Saleh, K. Wantijk, Hukum Acara Perdata (RBg/HIR), Ghalia Indonesia, Jakarta, 1981

Subekti, R. , Hukum Pembuktian, Pradnya Paramita, Jakarta, 2001

---, Hukum Perjanjian, Intermasa, Jakarta, 2005

Utomo, Hatta Isnaini Wahyu, Memahami Pelaksanaan Tugas Jabatan Pejabat Pembuat Akta Tanah, Phoenix Publisher, Yogyakarta, 2019

\footnotetext{
Jurnal, Makalah dan Karya Ilmiah

Karuniawan, Huddhan Ary, "Keabsahan Pemberian Barcode Pada Minuta Akta Dan Salinan Akta Notaris" , Jurnal Komunikasi Hukum, Volume 4 Nomor 2 Agustus 2018
} 
Putra, Ferdiansyah, "Perlindungan Hukum Terhadap Para Pihak Yang Dirugikan Atas Penyuluhan Hukum Oleh Notaris", Jurnal Komunikasi Hukum, Volume 4 Nomor 2 Agustus 2018

Setiawan, Wawan, Kedudukan dan Keberadaan Pejabat Umum serta PPAT di bandingkan dengan Kedudukan Pejabat Tata Usaha Negara Menurut Sistem Hukum Nasional, tanpa penerbit, Jakarta, 2001

Tumbuan, Fred B.G., "Tugas dan wewenang Organ Perseroan Terbatas Menurut Undangundang Tentang Perseroan Terbatas", Makalah, disampaikan pada "Sosialisasi Undang-undang tentang Perseroan Terbatas" yang diselenggarankan oleh Ikatan Notaris Indonesia (INI), Jakarta tanggal 22 Agustus 2007

Utomo, Hatta Isnaini Wahyu, "Pelaksanaan Tugas Jabatan Notaris : Bahan Diskusi Dalam Persiapan Menghadapi Ujian Kode Etik Notaris", Makalah, disampaikan pada acara Belajar Bareng Alumni, Universitas Narotama Surabaya, Februari 2018

Utomo, Hatta Isnaini Wahyu, "Penggunaan Surrogate Pada Akta Notaris", artikel dalam Kumpulan Tesis Pascasarjana Universitas Narotama 